\title{
Development of an in vivo method to better understand the obese skin
}

\section{Desenvolvimento de um método in vivo para melhor compreender a pele do obeso}

\author{
Liliana Tavares ${ }^{1}$, Lídia Palma ${ }^{1}, \mathbf{M}^{\mathbf{a}}$ Angélica Almeida ${ }^{3}, \mathbf{M}^{\mathbf{a}} \mathrm{Julia}_{\text {Bujan }}{ }^{4}$ \\ \& Luís Monteiro Rodrigues ${ }^{1,2}$ \\ ${ }^{1}$ Universidade Lusófona (CBIOS - Research Center for Health Science and Technologies), \\ Campo Grande, 376, 1749-024, Lisboa, Portugal \\ ${ }^{2}$ Dep. Pharmaceutical Sciences, Universidade de Lisboa - School of Pharmacy, Lisboa, Portugal \\ ${ }^{3}$ Serviço de Cirurgia Plástica e Reconstrutiva, HSJ-CHLC, Lisboa, Portugal \\ ${ }^{4}$ Universidade de Alcalá de Henares - School of Medicine, Madrid, Espanha \\ Email: tavaresliliana@sapo.pt
}

\begin{abstract}
The impact of obesity in the pathophysiology of human skin seems to be related to various dermatoses, basically resulting from the change in its normal physiology, including changes in the "barrier" and the "envelope" functions as well . However, the available information is still scarce due to the many complexities of the subject. This work aims to define an experimental methodology approach to objectively study the functional changes that characterize the obese skin.

This transversal study included 28 healthy volunteers, female (mean age $23 \pm 5$ years old), after informed consent. Skin functional characterization was obtained in one single measurement by non-invasive techniques, under controlled conditions. Relevant variables were hydration (superficial and deep), barrier function and biomechanical behavior, measured at four different anatomical areas. Through the SPSS (v 20.0) a univariate statistical analysis was performed to calculate central tendency and dispersion measures. The Pearson's and the Spearman's tests were chosen for those variables that followed, or not, a normal distribution, respectively, assuming a confidence level of $95 \%$. Results allow us to propose a methodology for the study of the skin applied to obese patients, including the choice of the anatomical areas and variables appropriate to the intended goal.
\end{abstract}

Keywords: normal skin, skin obese; TEWL, hydration, biomechanics

\begin{abstract}
Resumo
O impacto da obesidade na fisiopatologia da pele humana parece relacionar-se com diversas dermatoses, resultado da alteração da sua fisiologia normal, incluindo alterações na função barreira e na função de "envelope". Contudo, a informação disponível é ainda escassa devido às diversas complexidades do tema. Este trabalho pretende contribuir para a definição de uma metodologia de abordagem experimental para estudar, de forma objectiva, as alterações funcionais que caracterizam a pele obesa.

O presente estudo, transversal, incluiu 28 voluntárias, do sexo feminino, saudáveis, com idade média $23 \pm 5$ anos de idade, após consentimento informado. Foi realizada uma única medição de caracterização das diversas funções cutâneas obtidas por meios não invasivos em condições controladas. As variáveis consideradas relevantes foram, a hidratação (superficial e profunda) a função de barreira e o comportamento biomecânico, medidos em 4 áreas anatómicas distintas. Através do SPSS (v 20.0) realizámos uma análise estatística univariada com cálculo de medidas de tendência central e de dispersão. Recorremos aos testes de Pearson e de Spearman, para as variáveis que seguiam, ou não, uma distribuição normal, respectivamente, adoptando um grau de confiança de 95\% . Os resultados permitem propor uma metodologia para o estudo da pele, aplicável ao doente obeso, incluindo a escolha das áreas anatómicas e das variáveis adequadas ao objetivo pretendido.
\end{abstract}

Palavras-chave: pele normal; pele obesa; PTEA; hidratação, biomecânica 


\section{Introduction}

The World Health Organization (WHO) estimates, around the world, about one billion overweight people , of which 300 million are considered obese with a Body Mass Index (BMI) above $30 \mathrm{~kg} / \mathrm{m} 2{ }^{[1]}$. This overall dramatic increase, observed since 1980, led the WHO to consider it as an epidemic, and as such, a health problem.

The association between obesity and several comorbidities is well documented in the literature. This is the case of hypertension, coronary heart disease, diabetes and sleep apnea, as well as various dermatoses, probably due to changes in the barrier function, sebaceous glands secretion, or changes in (both macro and micro) cutaneous circulation ${ }^{[2-4]}$. The increase in transepidermal water loss (TEWL) ${ }^{[2,3,5]}$ and erythema ${ }^{[5]}$ as well as the modification of the skin's repair mechanisms ${ }^{[2-5]}$ are known. However, little information is still available and no information is sufficient to characterize the obese skin in its most frequent forms - visceral, where the fat accumulation occurs mainly in the abdominal area, and subcutaneous, in that this accumulation occurs mainly in lower limbs ${ }^{[6]}$. It is especially interesting to understand the impact of obesity in different anatomical regions, in view of the normal physiology of the skin, in particular where the fat preferentially accumulates. Also it is important to know if these changes determine other modifications and if they are related with the pathophysiological evidence we already know. Finally, it is interesting to consider the dramatic weight loss occurring in these patients undergoing surgical reduction procedures, determining new adaptation of the skin to another contour, with all the implied aesthetic aspects of reconstruction emerging ${ }^{[7,8]}$.

This study aims to develop a method contributing to the identification of the key biometric variables, select and identify anatomical regions as other factors conditioning the characterization of the skin to help define the skin obese functional status, when compared with normal skin.

\section{Material and Methods}

A convenience sample of 28 volunteers was selected. All female, aged between 19 and $46(23 \pm 5)$ years old, healthy, with normal BMI according to WHO criteria (between 19.9 and $24.9 \mathrm{~kg} / \mathrm{m} 2)^{[9,10]}$. BMI was calculated using the Quetelet's formula - BMI = weight/height ${ }^{2}$ expressed in $\mathrm{kg} / \mathrm{m} 2^{[11]}$. The volunteers were selected after informed consent, according to

\section{Introdução}

A organização mundial de saúde (OMS) estima que existam, em todo o mundo cerca de um bilião de pessoas com excesso de peso das quais, cerca de 300 milhões podem ser consideradas obesas, com um Índice de Massa Corporal (IMC) acima dos $30 \mathrm{Kg} / \mathrm{m}^{2}$ ${ }^{[1]}$. Este aumento dramático, global, observado desde 1980, levou a OMS a considerá-la uma epidemia, e, como tal um problema de saúde.

A associação entre obesidade e diversas comorbilidades está bem documentada na literatura. É o caso da hipertensão, da doença coronária, da diabetes e da apneia do sono, bem como de diversas dermatoses, provavelmente associadas a alterações na função barreira, das glândulas sebáceas e da circulação (macro e micro circulação) cutâneas ${ }^{[2-4]}$. O aumento da perda transepidérmica de água (PTEA) $)^{[2,3,5]}$ e do eritema $^{[5]}$, bem como a alteração da reparação cutânea ${ }^{[2-5]}$ são conhecidos. Contudo, a informação disponível é ainda escassa não existindo informação suficiente que permita caracterizar a pele obesa nas suas diferentes expressões mais frequentes - visceral, em que a acumulação de gordura se dá maioritariamente na zona abdominal e, subcutânea, em que essa acumulação se verifica maioritariamente nos membros inferiores ${ }^{[6]}$. É especialmente interessante conhecer o impacto da obesidade nas diferentes regiões anatómicas, tendo em vista a fisiologia normal da pele, em especial naquelas onde o tecido adiposo mais se desenvolve. Igualmente, importa saber ser a alteração dessas funções é responsável pela alteração de outras e, no limite, pelas evidências fisiopatológicas que conhecemos. Finalmente, interessa considerar a dramática perda de peso que muitos destes pacientes sofrem após terapêutica cirúrgica de redução, suscitando nova adaptação da pele a um outro contorno, com todos os aspectos estéticos e de reconstrução que daí emergem $^{[7,8]}$.

O presente estudo visa o desenvolvimento de uma metodologia que permita identificar as principais variáveis biométricas, regiões anatómicas e demais determinantes da caracterização da pele para contribuir para a definição funcional da pele obesa, quando comparada com a pele normal.

\section{Material e Métodos}

Foi selecionada uma amostra de conveniência de 28 voluntárias, do sexo feminino, com idades compreendidas entre os 19 e os 46 anos $(23 \pm 5$ anos de idade), saudáveis e com IMC considerado normal segundo os critérios da OMS (entre 19,9 e 24,9 
inclusion criteria previously established and in full compliance with all ethical standards from the Declaration of Helsinki and its amendments ${ }^{[12-15]}$. Non inclusion criteria were; being pregnant and / or lactation, presence of cutaneous signs in the experimental area, being a smoker, the existence of any type of topical treatment in the eight days preceding the study, the intense exposure to UV radiation, the regular practice of physical exercise and intense history of allergy to nickel or colophonia. Additionally, some restrictions were imposed, in particular, not to wash the anatomical area subject to measurement with soap or shower gel and no application of cosmetics in these areas, in the 24 hours preceding the measurements. The energy drinks intake was also restricted 48 hours prior to the study, as well as topical application of any treatment which might interfere with the study. All evaluations were carried out in the laboratory, under controlled temperature and humidity $\left(21 \pm 1^{\circ} \mathrm{C}, 45 \pm 5 \%\right)$ in the absence of heat and forced convection, according to previously published methods ${ }^{[16,17]}$. The "barrier" function was characterized by the transepidermal water loss (TEWL) measurement obtained with the Tewameter TM300 (CK electronics, FRD) expressed in $\mathrm{g} / \mathrm{m} 2 / \mathrm{h}$; the superficial epidermal hydration, was measured by the MoistureMeter SC ( Delphin Technology D) and Corneometer (CK electronics, FRP), in both cases expressed in AU (arbitrary units), and the "envelope" function assessed by the Cutometer CM575 (in mm) and expressed in AU and by the Reviscometer RV600, from CK electronics $\left(\mathrm{FRG}^{{ }^{[18-20]}}\right.$. In the cutometry, we used the measurement time / strain mode with three suction cycles from about 3 seconds followed by a relaxation period of about 2 seconds using a $8 \mathrm{~mm}$ diameter probe, and a constant suction pressure of 300 mbar. The chosen descriptors were ${ }^{[21-23]}$ :

- R0 or Uf maximum distension of the first curve

- R2 or Ua/Uf the elasticity of the skin, including pulse stretching and recovery

- R5 or Ur/Ue, the total elasticity

- R6, or Uv/Ue, or viscoelastic reason, the relationship between elastic and viscoelastic extension

- R8 or Ua from the first curve

obtained through the suction pulse that characterizes this method (Fig. 1)

For the reviscometer system, we selected the RRTm (Resonance Running Time - mean value) and anisotropy (obtained by dividing the ratio RRTmaximum/RRT minimum). RRT seems to be related to the mechanical behavior of the skin, and to increase directly with hydration ${ }^{[24,25]}$

Measurements were made on the face (zygomatic and frontal areas), on the ventral forearm, in the external
$\left.\mathrm{Kg} / \mathrm{m}^{2}\right)^{[9,10]}$. O IMC foi calculado, utilizando a fórmula de Quetelet's: IMC = peso/altura ${ }^{2}$, expresso em $\mathrm{Kg} / \mathrm{m}^{2}$ ${ }^{[11]}$. Os voluntários foram seleccionados após consentimento informado, de acordo com critérios de inclusão previamente estabelecidos e no pleno respeito de todas as normas éticas previstas pela Declaração de Helsínquia e respectivas emendas ${ }^{[12-15}$. Foram considerados como critérios de não-inclusão, o período de gravidez e/ou aleitamento, a presença de sinais cutâneos na área experimental, o ser fumador, a existência de qualquer tipo de tratamento tópico nos 8 dias anteriores ao estudo, a exposição intensa a radiação UV, a prática regular de exercício físico intenso e historial de alergia ao níquel ou à colofónia. Adicionalmente, foram impostas algumas restrições, nomeadamente o não lavar a área anatómica sujeita a medição com sabão ou gel de banho e a não aplicação de produtos cosméticos nessas áreas, nas $24 \mathrm{~h}$ que antecederam as medições. A toma de bebidas energéticas foi também restringida nas $48 \mathrm{~h}$ anteriores ao estudo, bem como a aplicação de qualquer tratamento tópico que pudesse interferir com o estudo. Todas as avaliações foram efectuadas em ambiente laboratorial, em condições de temperatura e humidade controladas $\left(21 \pm 1^{\circ} \mathrm{C} ; 45 \pm 5 \%\right)$, na ausência de fontes de calor e de convecção forçada, de acordo com metodologia e recomendações previamente publicadas ${ }^{[16,17]}$. A função de "barreira" foi caracterizada através da medida da perda transepidérmica de água (PTEA), obtida com o Tewameter TM300 (CK electronics, FRD) expressa em $\mathrm{g} / \mathrm{m}^{2} / \mathrm{h}$, a hidratação superficial epidérmica, medida através do Moisturemeter SC (Delphin Technology D) e do Corneometer (CK electronics, FRD), em ambos os casos expressa em UA (unidades arbitrárias), e a função de "envelope" avaliada através dos sistemas Cutometer CM575, (expressa em mm) e Reviscometer RV600 expressa em UA, da CK electronics $(F R G)^{[18-20]}$. Na cutometria, utilizamos o modo de medição time/strain com três ciclos de sucção, de cerca de $3 \mathrm{~s}$ seguidos por um período de relaxamento de cerca de $2 \mathrm{~s}$, utilizando uma sonda de $8 \mathrm{~mm}$ de diâmetro e uma pressão sucção constante de 300 mbar. Os descritores escolhidos foram ${ }^{[21-23]}$ :

- R0 ou Uf a distensão máxima da primeira curva

- R2 ou Ua/Uf a elasticidade total da pele, incluindo o pulso de distensão e de recuperação

- R5 ou Ur/Ue, a elasticidade total

- R6 ou Uv/Ue, ou razão viscoelástica, a relação entre a extensão viscoelástica e elástica

- R8 ou Ua da primeira curva

obtidos através do pulso de sucção que caracteriza este método (fig.1)

Para o sistema reviscometer, selecionamos o RRTm 
anterior face of the leg, in the breast and in the abdominal region. These last two areas are most important since are preferential accumulation areas with major translation either in weight gain or loss. To ensure that measurements were always performed in the same location within the selected anatomical area, a reference system was developed to always ensure the same probe's placing and that the measurement took place in the same location (fig.2 .)
(Ressonance Running Time - valor médio) e a Anisotropia (obtida pela razão entre o RRT máximo e o RRT mínimo). A medida do RRT, relacionada com o comportamento mecânico da pele, parece aumentar directamente com a hidratação ${ }^{[24,25]}$

As medições foram efetuadas na face (zonas zigomática e frontal), na face ventral do antebraço, na face Antero lateral externa da perna, na região mamária e na região abdominal. Estas duas últimas áreas são das mais importantes na medida em que correspondem aquelas que sofrem maiores alterações quer com o ganho quer com a perda de peso. De forma a garantir que as medições eram sempre realizadas no mesmo local, dentro da área anatómica selecionada, criámos um sistema de referenciação para colocação das sondas dos sistemas de avaliação, de forma a assegurar que a medição ocorre sempre no mesmo local (fig.2).

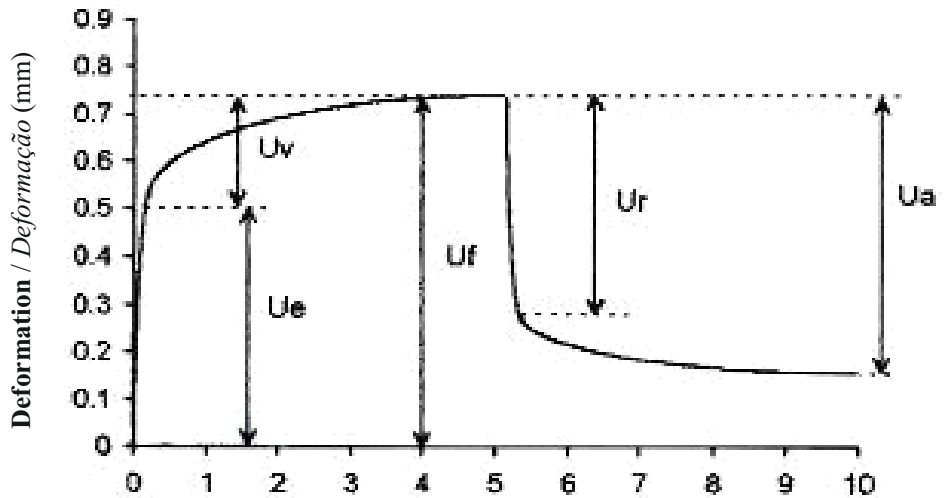

Figure 1 - Typical Stress-Strain relationship obtained with Cutometer 575 (CK electronics) (Ufmaximum distension afetre suction; Ue-elastic deformation; Ur-immediate elastic recovery; Uvviscoelasticity; Ua-maximum recovery).

Figura 1 - Relação stress / strain típica do Cutometer 575 (CK electronics) (Uf-distensão máxima da pele após sucção; Ue-deformação elástica; Urrecuperação elástica imediata; Uv-viscoelasticidade; Ua-recuperação máxima).
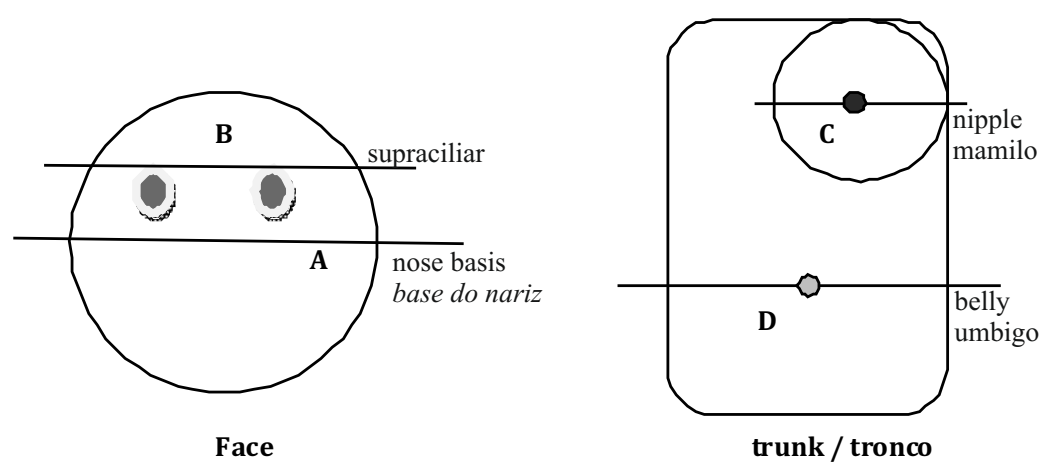

Figure 2 - Measurement reference scheme to illustrate how sites were marked. In the face, the zygomathic area was defined by a mid point in a line drawn between the nose apex and the auricular lobule apex (A) while in the front B is the central point between the hairline and the supracilliar line; in the breast measurement took place in the right inferior quadrant $2 \mathrm{~cm}$ apart from the nipple midline; in the abdomen, measurement took place in the right hypograstric region, $2 \mathrm{~cm}$ bellow the belly midline.

Figura 2 - Esquema de referenciação dos locais de medição. Na face, a zona zigomática foi determinada, considerando o ponto médio de uma linha imaginária entre a ponta do nariz e a ponta do lóbulo auricular (A); na fronte foi considerada a zona central, entre a linha do cabelo e a linha supraciliar (B); na mama as medições ocorreram no quadrante inferior direito, $2 \mathrm{~cm}$ abaixo da linha média do mamilo; no abdómen, as medições tiveram lugar no hipogástrico direito, $2 \mathrm{~cm}$ abaixo da linha média do umbigo. 
Statistical analysis (descriptive and comparative) was performed using SPSS (v 20.0) by univariate analysis to calculate measures of central tendency and dispersion. The Pearson's and the Spearman's tests were also chosen to compare data, according to the variables distribution (normal or not, respectively), assuming a confidence level of $95 \%$.

\section{Results and Discussion}

Table 1 summarizes the quantitative data obtained in all anatomical locations within the sample.
A análise estatística (descritiva e comparativa) foi realizada através do programa SPSS (v 20.0) utilizando uma análise univariada com cálculo de medidas de tendência central e de dispersão. Recorremos ainda aos testes de Pearson e Spearman de acordo com a distribuição (normal ou não, respectivamente) das variáveis, adoptando um grau de confiança de $95 \%$.

\section{Resultados e Discussão}

A tabela 1 resume os dados quantitativos obtidos em todas as zonas anatómicas nesta amostra.

Table 1 - Normal skin functional data obtained from the studied volunteers group $(n=28)$

Tabela 1 - Dados funcionais da pele normal obtidos no grupo de voluntários em estudo $(n=28)$

\begin{tabular}{|c|c|c|c|c|c|c|c|c|}
\hline \multirow{2}{*}{ Variables / Variáveis } & & \multicolumn{7}{|c|}{ Anatomical area / Área anatómica } \\
\hline & & $\begin{array}{l}\text { hand / } \\
\text { mão }\end{array}$ & $\begin{array}{l}\text { forearm / } \\
\text { antebraço }\end{array}$ & $\begin{array}{l}\text { leg / } \\
\text { perna }\end{array}$ & face $A$ & face B & $\begin{array}{l}\text { breast / } \\
\text { mama }\end{array}$ & abdomen \\
\hline TEWL / PTEA & mean / média & 7,39 & 6,49 & 5,70 & 12,57 & 10,69 & 5,23 & 6,77 \\
\hline$(\mathrm{g} / \mathrm{m} 2 / \mathrm{h})$ & $s d / d p$ & 2,57 & 1,92 & 2,32 & 4,27 & 2,74 & 3,61 & 2,70 \\
\hline "Capacitance" / "capacitância" & mean / média & 39,90 & 34,73 & 42,50 & 51,79 & 49,46 & 52,75 & 39,64 \\
\hline (UA) & $s d / d p$ & 10,18 & 8,53 & 8,89 & 11,07 & 11,43 & 15,17 & 13,31 \\
\hline RRTm & mean / média & 152,00 & 164,43 & 79,67 & 145,05 & 134,47 & 228,28 & 249,66 \\
\hline (UA) & $s d / d p$ & 29,55 & 26,67 & 19,88 & 45,64 & 45,08 & 67,65 & 53,80 \\
\hline Anisotropia/ anisotropy & mean / média & 87,13 & 93,29 & 30,79 & 1,94 & 1,93 & 2,93 & 2,07 \\
\hline (UA) & $s d / d p$ & 37,85 & 42,74 & 28,47 & 0,81 & 1,48 & 1,89 & 0,87 \\
\hline RO (Uf) & mean / média & 0,94 & 0,77 & 0,27 & 1,28 & 0,84 & 0,85 & 1,39 \\
\hline$(\mathrm{mm})$ & $s d / d p$ & 0,43 & 0,26 & 0,11 & 0,85 & 0,49 & 0,25 & 0,38 \\
\hline R2 (Ua/Uf) & mean / média & 0,85 & 0,87 & 0,81 & 0,63 & 0,70 & 0,89 & 0,87 \\
\hline (UA) & $s d / d p$ & 0,14 & 0,06 & 0,08 & 0,25 & 0,20 & 0,07 & 0,13 \\
\hline R5 (Ur/Ue) & mean / média & 1,00 & 1,06 & 1,00 & 0,60 & 0,67 & 1,03 & 0,92 \\
\hline (UA) & $s d / d p$ & 0,24 & 0,18 & 0,19 & 0,31 & 0,24 & 0,31 & 0,28 \\
\hline R6 (Uv/Ue) & mean / média & 0,38 & 0,43 & 0,45 & 0,33 & 0,43 & 0,52 & 0,31 \\
\hline (UA) & $s d / d p$ & 0,14 & 0,16 & 0,14 & 0,18 & 0,17 & 0,13 & 0,14 \\
\hline R8 (Ua) & mean / média & 0,77 & 0,67 & 0,22 & 0,63 & 0,54 & 0,76 & 1,20 \\
\hline$(\mathrm{mm})$ & $s d / d p$ & 0,28 & 0,26 & 0,11 & 0,24 & 0,26 & 0,24 & 0,29 \\
\hline
\end{tabular}




\begin{tabular}{lcc}
\hline & $\begin{array}{c}\text { TEWL_b } \\
P T E A \_m\end{array}$ & $\begin{array}{c}\text { HS_abd } \\
H S \_a b d\end{array}$ \\
\hline A_b & & \\
$A \_m$ & 0,57 & \\
\hline RRTm_b & & \\
RRTm_m & 0,6 & \\
\hline Ur/Ue_abd \\
Ur/Ue_abd
\end{tabular}

The results of the analysis allowed us to chose the anatomical areas, taking into account the locations where the gain or weight loss are greater also meaning where those changes will demand further aesthetic correction after weight loss. So, we found it interesting to consider four anatomical areas - in the face, the forehead and the zygomatic area, in the trunk the lower quadrant of the breast and in the abdomen, the hypogastrium.

In order to assess the extent to which epidermal elasticity and moisture were related, we assessed the correlation between variables, using the Pearson and the Spearman tests, depending on the presence, or not ,of a normal distribution, respectively.

The most significant result, and therefore the more relevant, is the existence of a positive correlation, although weak, between the variables measured by reviscometry, anisotropy in the breast area and RRTm measures of elasticity, breast and TEWL (respectively, $r=0.57$ and $r=0.60$ ). This positive correlation allows us to consider that both variables might change in the same direction. An interesting negative correlation between the variable Ur / Ue (R5) (measure of elasticity) and the superficial hydration $(\mathrm{r}=-0.51)$ leads us to consider a possible dependence between these two variables. In fact we did not find any statistically significant relationship between elasticity and hydration (Table 2).

This transversal study seems to set the foundation for the methodology to be applied to obese patients. It constitutes a control group which is essential in establishing the differences that we expect to find in comparison with normal skin.
Table 2 - Correlation between variables (Spearman's test) obtained in different anatomical regions (b-breast ; abd-abdomen)

Tabela 2 - Correlação entre variáveis (teste de Spearman) obtida em diferentes regiões anatómicas (mmama; abd-abdomen)

Após a análise dos resultados, foram escolhidas as áreas anatómicas, tendo em conta as zonas onde o ganho ou a perda de peso se manifesta com maiores modificações e, onde se revela mais necessária a ulterior intervenção estética após perda ponderal. Desta forma, entendemos considerar como mais relevantes 4 áreas anatómicas - na face, a zona zigomática e a fronte, no tronco o quadrante inferior da mama e no abdómen, a região hipogástrica.

Tendo em vista avaliar em que medida a elasticidade e a hidratação epidérmica se encontram relacionadas, avaliámos a correlação entre as variáveis, através dos testes Pearson e de Spearman, consoante em presença, ou não, de uma distribuição normal, respectivamente.

Os resultados que destacamos como significativos e, portanto, mais relevantes, são os da existência de uma correlação positiva, embora fraca, entre as variáveis medidas pela reviscometria anisotropia na zona mama e RRTm, medidas de elasticidade, e PTEA na mama (respectivamente, $r=0,57$ e $r=0,60$ ). Esta correlação positiva permite-nos considerar uma possível variação, no mesmo sentido, das duas variáveis. Deteta-se ainda uma correlação (negativa) entre a variável $\mathrm{Ur} / \mathrm{Ue}$ (R5) (medida de elasticidade) e a hidratação superficial $(r=-0,51)$ o que nos leva a considerar uma possível dependência entre as variáveis de elasticidade e hidratação. Na face não encontrámos qualquer relação estatisticamente significativa entre as variáveis de elasticidade e hidratação (tabela 2).

Este estudo transversal lança assim, as bases da metodologia que deverá ser aplicada aos doentes obesos, constituindo um grupo de controlo essencial para estabelecer as diferenças que esperamos encontrar face à pele normal. 


\section{Acknowledgements}

To Professor Paulo Morais and Carla Monteiro for helping with statistics.

\section{Conflict of Interest}

The authors declare that there is no financial or personal relationship that can be understood as representing a potential conflict of interest.

\section{Agradecimentos}

Ao Professor Paulo Morais e à Mestre Carla Monteiro pela ajuda com o tratamento estatístico dos dados.

\section{Conflito de Interesses}

Os autores declaram não existir qualquer relação pessoal ou financeira que possa ser entendida como representando um potencial conflito de interesses.

\section{References / Referências}

[1] Formiguera X, Cantón A. Obesity: epidemiology and clinical aspects. Best Practice \& Research Clinical Gastroenterology Vol. 18, No. 6, pp. 1125-1146, 2004

[2] Yosipovich G, De Vore A, Dawn A. Obesity and skin: Skin physiology and skin manifestations of Obesity. J AmAcad Dermatol, 2007;6: 901-16.

[3] Nino M, Franzese A, Ruggiero Perrino N, Balato N. The Effect of Obesity on Skin Disease and Epidermal Permeability Barrier Status in Children. Pediatr Dermatol. 2012 Apr 4.

[4] Guida B, Nino M, Perrino NR, Laccetti R, Trio R, Labella $\mathrm{S}$, Balato N, The impact of obesity on skin disease and epidermal permeability barrier status. J Eur Acad Dermatol Venereol. 2010 Feb;24(2):191-5. Epub 2009 Nov 19.

[5] Löffler H, Aramaki JU, Effendy I. The influence of body mass index on skin susceptibility to sodium lauryl sulphate. Skin Res Technol. 2002 Feb;8(1):19-22

[6] Matsuzawa Y, Shimomura I, Nakamura T, Keno Y, Kotani K, Tokunaga K. Pathophysiology and pathogenesis of visceral fat obesity. Obes Res. 1995 Sep;3 Supp1 2:187S-194S.

[7] Sebastian JL. Bariatric surgery and work-up of the massive weight loss patient. Clin Plast Surg. 2008 Jan; 35 (1):11-26

[8] Shermak MA, Rotellini-Coltvet LA, Chang D. Seroma development following body contouringsurgery for massive wheight loss: patient risk factos and treatment srtategies. Plast Reconstr Surg. 2008, Jul-, 122(1): $280-8$

[9] WHO expert consultation. Appropriate body-mass index for Asian populations and its implications for policy and intervention strategies. The Lancet, 2004 157-163.

[10] WHO, Physical status: the use and interpretation of anthropometry. Report of a WHO Expert Committee. WHO Technical Report Series 854. Geneva: World Health Organization, 1995

[11] Garrow JS, Welster J. Quetelet's index (W/H2) as a measure of fatness. Int J Obes 1985; 9: 147-153.

[12] República, Lei 46/2004 de 19 de Agosto.

[13] EUROPEAN DIRECIVE 2001/20/EC on the approximation of the laws, regulations and administrative provisions of the Member State relating to the implementation of good clinical practice in the conduct. Of clinical trials on medicinal products for human use, Off $\mathrm{J}$
Europ Communities, L121/34-44, 2001.

[14] Note for Guidance on Good Clinical Practice, ICH E6GCP96, EMEA, 2002: 1-55.

[15] World Medical Association declaration of Helsinky. Ethical Principles for Medical Research Involving Human subjects, amended until 2004 Rogiers V

[16] ; EEMCO Group. EEMCO guidance for the assessment of transepidermal water loss in cosmetic sciences. Skin Pharmacol Appl Skin Physiol 2001;14 (2):117-28.

[17] Piérard GE, EEMCO guidance to the in vivo assessment of tensile functional properties of the skin. Part 1: relevance to the structures and ageing of the skin and subcutaneous tissues. Skin Pharmacol Appl Skin Physiol. 1999;12(6):352-62

[18] Rodrigues L; EEMCO, EEMCO guidance to the in vivo assessment of tensile functional properties of the skin. Part 2: instrumentation and test modes. Skin Pharmacol Appl Skin Physiol. 2001;14(1):52-67.

[19] Darlenski R, Sassning S, Tsankov N, Fluhr JW. Non-invasive in vivo methods for investigation of the skin barrier physical properties. Eur J Pharm and Biopharm. 2009, 72:295-303 